\title{
Methodology for accelerated monitoring and assurance of sanitary quality and food safety
}

\author{
Inna Pylypenko ${ }^{1}$, Liudmyla Pylypenko, \\ AnnaYamborko², Olena Danylova ${ }^{2}$
}

\author{
1 - Odesa National Academy of Food Technologies, Odesa, Ukraine \\ 2 - Odesa I. I. Mechnikov National University, Odesa, Ukraine
}

Keywords:

Food

Sanitary

Safety

Phenotypic

Genotypic

Control

PCR.

\section{Article history:}

Received 14.03.2017

Received in revised

form 22.05.2017

Accepted 29.06.2017

\section{Corresponding \\ author:}

Liudmyla Pylypenko

E-mail:

1.n.pylypenko@ukr.net

DOI: $10.24263 / 2304-$

974X-2017-6-2-4

\section{Abstract}

Introduction. The microbiological criteria that ensure sanitary quality and safety of food products, methods for identifying regulated microorganisms, and the urgency of accelerated microbiological control of food safety are characterized.

Materials and methods. The methodology for assessing the safety of products and the classical and accelerated methods for determining regulated microbiological indicators that identify the presence of heat-resistant pathogens of food diseases are studied. Analytical studies are based on modern literary sources and some of own results.

Results and discussion. The characteristics of microbiological criteria and requirements for microbiological safety of food products were given. Analysis of modern requirements for the sanitary safety of food has shown the need for microbiological control for the presence of heat-resistant microorganisms, which are potential pathogens of foodborne diseases. Microbial species traditionally the main assessment of their health status such as Clostridium botulinum, Bacillus cereus, Clostridium perfringens, Staphylococcus aureus were given. Characteristics of the phenotypes and genotypic properties of criterial microorganisms - potential causative agents of foodborne infections and poisonings are given. The study methodology and methods of control of regulated microorganisms showed failure and inaccuracy of their phenotypic diagnosis due to the similarity of morphological and tinctorial properties within the individual groups, the variability of a number of biochemical parameters, weak antigenicity for the immunological diagnosis, the advent of new metabolic features associated with the ability to synthesize genes toxicity by microorganisms, which were traditionally considered to be nonpathogenic, labor-consuming and durable analysis. Genotypic diagnostics of microorganisms using modern molecular genetic methods and methodologies, in contrast to the phenotypic one, ensures the accuracy of identification, the ability to monitor and predict the behavior of pathogens of foodborne infections and toxic infections in products in assessing microbiological risk, allows accelerated microbiological control of food safety, taking into account their specific features of composition and properties, is a reliable method of sanitary control.

Conclusions. Molecular genetic diagnosis of pathogens is a promising accelerated method for determining food safety and is relevant especially in the Ukrainian region. 


\section{Introduction}

The characteristics of microorganisms that are criterial in assessing the microbiological safety of food, of the methodology and methods for identifying biological pollutants occurring in food products - agents of foodborne infections and poisoning, identifying a potential danger to the consumer with accelerated and reliable methods for controlling food safety, are relevant.

The aim of the research is to investigate the criteria indicators of sanitary quality and food safety, methodology and methods for accelerated control of thermally stable regulated microorganisms - potential causative agents of food poisoning.

Microbiological criteria for food safety. Biological hazards are the main ones in assessing the degree of risk if they are caused by the presence of microorganisms in foodstuffs such as bacteria or products of their vital activity, toxigenic molds, viruses; parasites - helminths and protozoa, as well as insects that are potential carriers of pathogenic microorganisms $[1,2,3]$. According to statistics, annual economic losses due to diseases caused by several pathogenic microorganisms in the US amount to 35 billion dollars, in Australia - up to 2.6 billion Australian dollars, and social losses are irreplaceable $[4,5]$.

The reason for increasing the level of biological hazards is the modern fashion for the consumption of raw or minimally cooked food, the increase in the share of products of animal origin, improperly prepared or stored long before consumption, through the expansion of international trade in new types of food raw materials that have changed the overall a picture of microbiological hazards, a modification of the microorganisms themselves [5-7].

The Codex Alimentarius Commission has developed guidance documents CAC/GL 21, «Principles for the Establishment and Application of Microbiological Criteria for Food Products», CAC/GL-30 «Principles and Guidelines for Microbiological Risk Assessment», where requirements for microbiological safety of food are set out, as well as microbiological criteria establishing general risk assessment rules that can be used are indicated [8-10]:

- to check the conformity of the technological process with the requirements of good hygiene practice (GHP) and GMP (good manufacturing practice) - good manufacturing practices and hygiene practices;

- to determine the suitability or unsuitability of the product or batch of products presented for delivery to the market or already in the sphere of trade;

- to determine the acceptability or unacceptability of new products and new technology in terms of ensuring microbiological safety;

- to develop trade agreements between the supplier and the recipient of the products.

General considerations regarding the principles for the development and application of microbiological criteria for different types of food are given in the Codex Alimentarius $\mathrm{CAC} / \mathrm{GL} 21$ document and other EU policy documents, for example, in the report of the EU Commission «On the strategy for selecting microbiological criteria for food in the EU food legislation», in the EU Guidelines 2073 «On Microbiological Criteria for Food», as well as in the guidelines of the Federal Food and Drug Administration (USA) [1, 4, 11-13]:

- if it is a question of products with a short shelf life or products of increased demand that are not delayed in the trade network, the method used must be fast enough so that the time taken to obtain information about the safety of the product does not exceed the period of storage or shelf life; 
- microbiological criteria should be established only when there is a need for them (for example, in connection with a special epidemiological situation);

- when determining the criteria, such circumstances as the actual or potential health hazard, the microbiological status of the raw material, the influence of technological methods on the microbiological status of the finished product, the possibility of recontamination of the finished product or the possibility of microorganisms developing in it at subsequent stages of the technological or life cycle, category of consumers, for which the product is intended, the way in which the product is used, the ratio between the costs of control and profit;

- both pathogenic and indicator organisms can be used as controlled microorganisms; Instead of microorganisms, their toxins can be controlled;

- in cases where the pathogens themselves can be isolated reliably, preference should be given to their direct control, and not to indirect monitoring by indicator microorganisms;

- as for the choice of analytical methods, it should be borne in mind that for carrying out comparative tests in different laboratories only those methods can be used whose reliability is as far as possible estimated, i.e., statistical indicators of the accuracy of the results obtained, convergence and reproducibility of the analysis results, In different laboratories of comparative trials can only be used;

- test methods intended for use in controversial situations should have greater selectivity and reproducibility of results than the methods used in the production environment (which, in return for these qualities, should have other advantages, such as speed and ease of obtaining the necessary information);

- the limits should be established not for individual products but for groups of homogeneous products, and therefore should be based on the input data obtained for all such products manufactured under the operating conditions of the HACCP system and GMP-good manufacturing practices;

- when establishing microbiological criteria, consideration should be given to the possibility of changing the microflora of the product during its storage during the specified shelf life, as well as during its redistribution, taking into account the conditions for storage and transportation of the product, as well as the process of its preparation for use (if it is required);

- if the microbiological criterion requires a lack of a microorganism in the product, the mass or volume of the analytical sample and the number of analytical samples must be indicated.

Modern sources note $[4,7,12]$ that selective control of finished products by microbiological indicators can not provide the required security guarantees. The necessary level of microbiological safety of food products can be achieved only through measures of a preventive nature and mainly through compliance with and control of sanitary norms and rules, and through the application of control procedures based on the principles of hazard analysis and control of critical points in the processing and redistribution processes food (implementation of the principles of the HACCP system) [12].

Requirements for the biological safety of food products. The focus of attention of hygienists are currently following bacteria, which become sources of food poisoning and infections: microorganisms of the genus Salmonella, Clostridium botulinum, Clostridium perfringens, Staphylococcus aureus, Campilobacter jejuni, Yersinia enterocolitica and Yersinia pseudotuberculosis, Listeria monocytogenes, Vibrio cholerae $O$ and non- O-1, Vibrio parahaemolyticus, Vibrio vulnificus and other representatives of the genus Vibrio, 
Aeromonas hidrophila, Plesiomonas shigelloides, Shigella, bacteria group Miscellaneous enterics, Streptococcus, and Escherichia coli [2, 12, 14, 15].

The risk of alimentary diseases make their share as viruses - Hepatitisvirus, Rotavirus, Norvalk virus etc., as well as parasites such as Helminths and intestinal pathogenic protozoa, whose source can be water, shellfish, sick animals and humans. Among the viruses that cause nutritional disorders, it should be noted Hepatitis ( $A$ and E) virus, Rotavirus, Norwalk, and among this organisms infesting and worms [1,2].

The subject of constant supervision should not be absolutely all the listed microorganisms, viruses and parasites. Modern food safety systems require control only over the most dangerous sources of risk, different for different types of food products. Therefore, one of the key stages in the development of a security management system, including HACCP systems for each specific type of food, is to assess the magnitude of the risk and to decide whether or not a particular control effort is appropriate.

Particular attention from these positions should be given to long-term storage products - to various types of canned, dried foods, semi-canned foods. Depending on the type of heat treatment - sterilization, sub-sterilization, pasteurization or hot packing, the residual microflora can be represented by different types of microorganisms [16, 17]. The causative agents of food poisoning, found among the residual and secondary microflora of full canned food, are sporiferous microorganisms (Clostridium botulinum, Bacillus cereus, Clostridium perfringens), and in semis - also staphylococci (Staphylococcus aureus).

\section{Materials and methods}

The methodology and methods for assessing the safety of products with the use of classical methods for determining phenotypic indicators of regulated microorganisms were investigated. There were such parameters of regulated microorganisms studied as morphological, tinctorial, cultural, biochemical, physiological, some chemotaxonomic properties (some of them listed in Table 1) [5, 12, 17-19, 21-23, 25-26, 36] and others. Methods for rapid determination of regulated microbiological parameters that identify the presence of heat-resistant food pathogens diseases are based on the determination of molecular genetic features [24, 31-32, 37-38, 44-52]. The analytical studies are performed on the basis of modern literary sources and some of own results [27, 34, 35, 39-42].

\section{Results and discussion}

1. Characteristics and traditional methods of diagnosis of regulated microorganisms, which are the causative agents of food poisoning

A brief generalized phenotypic characteristic of the causative agents of food poisoning that occur in the residual and secondary microflora of products of long-term storage, as well as their effect on the properties of food products, are given in Table $1[5,12,17-19$, etc]. 
Table 1

The main characteristics of the causative agents of food poisoning from the residual and secondary microflora of long-term storage products

\begin{tabular}{|c|c|c|c|}
\hline $\begin{array}{l}\text { Microorganism } \\
\text { type, } \\
\text { Determination } \\
\text { method }\end{array}$ & $\begin{array}{l}\text { Morphology and } \\
\text { tinctorial features }\end{array}$ & $\begin{array}{c}\text { Physiological and } \\
\text { some biochemical } \\
\text { properties }\end{array}$ & $\begin{array}{c}\text { Impact on product } \\
\text { quality, } \\
\text { toxigenicity }\end{array}$ \\
\hline $\begin{array}{l}\text { Clostridium } \\
\text { botulinum, } \\
\text { ISO/TS } \\
\text { 17919:2013, } \\
{[19,26]}\end{array}$ & $\begin{array}{l}\text { Spore-forming large } \\
\text { rod-shaped bacterium } \\
\text { with rounded ends } \\
\text { measuring }(0.3-4.3) \mathrm{x} \\
(3.4-8.6) \mathrm{mkm} \text {, at } \\
\text { young age is mobile, } \\
\text { gram positive. Spores } \\
\text { oval, subterminal, a cell } \\
\text { with a spike resembles } \\
\text { a tennis racket }\end{array}$ & $\begin{array}{l}\text { Mesophilus, severe } \\
\text { anaerobic. Catalazo- } \\
\text { negative, splits gelatin. } \\
\text { Lactose, sucrose, } \\
\text { mannitol does not } \\
\text { ferment, nitrates do } \\
\text { not reduce, indole } \\
\text { does not form. The } \\
\text { fermentation of } \\
\text { glucose, maltose and } \\
\text { salicin varies. } \\
\text { Proteolytic strains A, } \\
\text { B decompose casein, } \\
\text { non-proteolytic B, E, } \\
\mathrm{F}-\text { do not decompose } \\
\text { milk casein. There are } \\
\text { eight types of } \\
\text { botulinum toxins } \\
\text { differentiated in } \\
\text { neutralization } \\
\text { reactions with type- } \\
\text { specific diagnostic } \\
\text { antibotulinum sera. } \\
\text { Thermostability at pH } \\
7.0 \text { for } C \text {. botulinum A } \\
\text { and B corresponds to } \\
\mathrm{D}_{121}=0.2 \text { min, for } \\
\text { type E } \mathrm{D}_{80}=1.8 \text { min. } \\
\text { The toxin formation } \\
\text { and multiplication of } \\
C . \text { botulinum is } \\
\text { observed under strictly } \\
\text { anaerobic conditions } \\
\text { at a pH above } 4.2 \\
\text { (usually in media with } \\
\text { a pH of } 4.5-8.0 \text { ), with } \\
\text { a NaCl concentration } \\
\text { of not more than } 10 \% \\
\text { and a sugar content of } \\
\text { not more than } 50 \% \text {. }\end{array}$ & $\begin{array}{l}\text { Botulinum toxin can } \\
\text { accumulate without } \\
\text { visible changes in the } \\
\text { product. Human disease } \\
\text { is usually associated } \\
\text { with intoxication } \\
\text { caused by C. botulinum } \\
\text { types A, B, E, less often } \\
\text { F. The disease caused } \\
\text { by } C \text {. botulinum type A } \\
\text { is most often very } \\
\text { severe, lethality is } 60 \text { - } \\
70 \% \text { of cases. Diseases } \\
\text { associated with types B } \\
\text { and E are characterized } \\
\text { by a lighter course } \\
\text { (lethality } 10-30 \% \text { ). The } \\
\text { development of } C \text {. } \\
\text { botulinum under } \\
\text { favorable conditions } \\
\text { (pH above } 4.2 \text {, water } \\
\text { activity ( } \mathrm{a}_{\mathrm{w}} \text { ) above } \\
0.85 \text { ) leads to the } \\
\text { bombing of cans and } \\
\text { packages, the product } \\
\text { acquires a foreign } \\
\text { smell, most o ften of } \\
\text { butyric acid. }\end{array}$ \\
\hline
\end{tabular}




\begin{tabular}{|c|c|c|c|}
\hline & & & Table 1 (Continue) \\
\hline $\begin{array}{l}\text { Microorganism } \\
\text { type, } \\
\text { Determination } \\
\text { method }\end{array}$ & $\begin{array}{l}\text { Morphology and } \\
\text { tinctorial features }\end{array}$ & $\begin{array}{l}\text { Physiological and some } \\
\text { biochemical properties }\end{array}$ & $\begin{array}{c}\text { Impact on product } \\
\text { quality, } \\
\text { toxigenicity }\end{array}$ \\
\hline $\begin{array}{l}\text { Clostridium } \\
\text { perfringens, ISO } \\
\text { 7937:2004 }\end{array}$ & $\begin{array}{l}\text { Large, straight } \\
\text { thick sticks with } \\
\text { rounded or blunt } \\
\text { ends with a size } \\
(0,9-1,3) \text { x }(4,0- \\
8,0) \text { mkm. The size } \\
\text { of the cells depends } \\
\text { on the strain of } \\
\text { clostridia, age and } \\
\text { substrate. The cells } \\
\text { are arranged in } \\
\text { groups parallel to } \\
\text { each other, stacked } \\
\text { in pairs, in pairs, } \\
\text { singly, more rarely } \\
\text { - by a chain. Can } \\
\text { form a capsule. } \\
\text { Gram-positive, in } \\
\text { old cultures, } \\
\text { mosaic staining is } \\
\text { possible - cells } \\
\text { appear that are } \\
\text { repetitively gram- } \\
\text { negative. The } \\
\text { diagnostic sign is } \\
\text { immobility of cells. } \\
\text { Spores oval, central } \\
\text { or subterminal. In } \\
\text { contrast to } \\
\text { causative agents of } \\
\text { botulism, the cell } \\
\text { does not swell } \\
\text { during sporulation }\end{array}$ & $\begin{array}{l}\text { Mesophilic anaerobes (the } \\
\text { optimum temperature is } 37 \\
{ }^{\circ} \mathrm{C} \text {, but } C \text {. perfringens can } \\
\text { grow over a wide range of } \\
\text { temperatures - from } 16 \text { to } \\
50{ }^{\circ} \mathrm{C} \text { ). The optimum pH } \\
\text { value is } 6.7-7.6 \text {, but they } \\
\text { develop well in products } \\
\text { with pH } \geq 5.3 \text {, in some } \\
\text { canned foods with a pH of } \\
3.5-5.3 \text {. The optimum } \\
\text { value of } \mathrm{a}_{\mathrm{w}} \text { for the growth } \\
\text { of } C \text {. perfringens is } 0.95- \\
0.96 \text {, the minimum value is } \\
0.93 . \text { Limit the } \\
\text { development and toxin } \\
\text { formation in } C \text {. perfringens } \\
\text { table salt at a concentration } \\
7.4-12 \% \text { and carbohydra- } \\
\text { tes } 7-15 \% \text {. } \\
\text { They have a sulphite- } \\
\text { reducing ability, cause a } \\
\text { rapid fermentation of milk } \\
\text { with the formation of a } \\
\text { spongy bunch, as a rule, } \\
\text { decompose gelatin, form } \\
\text { lecithinase, hemolysins, } \\
\text { collagenase, and carry out } \\
\text { haemolysis. Six types of } C \text {. } \\
\text { perfringens are known: A, } \\
\mathrm{B}, \mathrm{C}, \mathrm{D}, \mathrm{E} \text { and } \mathrm{F} \text {, which are } \\
\text { distinguished by the } \\
\text { antigenic structure and } \\
\text { antigenic properties of the } \\
\text { toxins they produce. } \\
\text { Spores thermostability } \mathrm{D}_{90} \\
=5-145 \text { min. }\end{array}$ & $\begin{array}{l}\text { Widespread in soils and } \\
\text { water. Food poisoning } \\
\text { is associated with the } \\
\text { formation and sprouting } \\
\text { of } C \text {. perfringens spores } \\
\text { in the gastrointestinal } \\
\text { tract. Food poisoning is } \\
\text { caused mainly by } \\
\text { strains A and D. Food } \\
\text { poisoning of people is } \\
\text { associated with A-toxin, } \\
\text { the production of } \\
\text { enterotoxin and a } \\
\text { number of enzymes } \\
\text { with toxic properties. } \\
\text { As an exception, with } \\
\text { massive contamination } \\
\text { of C.perfringens } \\
\text { product, a bombing is } \\
\text { possible. }\end{array}$ \\
\hline
\end{tabular}




\begin{tabular}{|c|c|c|c|}
\hline \multicolumn{4}{|r|}{ Table 1 (Continue) } \\
\hline $\begin{array}{c}\text { Microorganism } \\
\text { type, } \\
\text { Determination } \\
\text { method }\end{array}$ & $\begin{array}{l}\text { Microorganism type, } \\
\text { Determination method }\end{array}$ & $\begin{array}{c}\text { Microorganism type, } \\
\text { Determination } \\
\text { method }\end{array}$ & $\begin{array}{l}\text { Microorganism type, } \\
\text { Determination method }\end{array}$ \\
\hline $\begin{array}{l}\text { Bacillus cereus, } \\
\text { ISO 7932:2004 }\end{array}$ & $\begin{array}{l}\text { Large movable rods } \\
\text { with straight or rounded } \\
\text { ends, gram-positive. } \\
\text { Dimensions (1.0- } \\
\text { 1.2)x(3.0-5.0) mkm are } \\
\text { located. In the form of } \\
\text { stacker-like clusters, } \\
\text { chains, occasionally } \\
\text { singly. Can form long } \\
\text { threads. Spores } \\
\text { cylindrical, ellipsoidal, } \\
\text { are located centrally or } \\
\text { eccentrically, the cell is } \\
\text { not inflated. Capsule } \\
\text { does not form }\end{array}$ & $\begin{array}{l}\text { Mesophilic aerobes or } \\
\text { facultative anaerobes. } \\
\text { Catalase-positive. } \\
\text { Grow in at } \\
\text { temperatures from } 8 \text { to } \\
50^{\circ} \mathrm{C} \text {, the optimum } \\
\text { temperature is } 30-32 \\
{ }^{\circ} \mathrm{C} \text {, at } \mathrm{pH} \geq 4.0,8 \% \\
\text { concentration of } \mathrm{NaCl} \text {. } \\
B \text {. cereus form acetoin } \\
\text { acetylmethylcarbinol, } \\
\text { most strains form } \\
\text { lecithinase, do not } \\
\text { form acid from } \\
\text { mannitol. }\end{array}$ & $\begin{array}{l}\text { Widespread in the } \\
\text { environment, in soil, in } \\
\text { products. Causes food- } \\
\text { borne diseases of } \\
\text { diarrhea and emetic } \\
\text { types. Accumulation in } \\
\text { the product of a large } \\
\text { number of cells ( } 10^{6} \text { - } \\
10^{7} \text { or more in } 1 \mathrm{~g} \text { ) } \\
\text { usually leads to minor } \\
\text { changes in the } \\
\text { appearance of the } \\
\text { product. When } \\
\text { developing in crushed } \\
\text { and homogenized } \\
\text { products (minced meat, } \\
\text { cutlets, cream, sausage), } \\
\text { their organoleptic } \\
\text { properties can change } \\
\text { significantly - a grayish } \\
\text { film forms on the } \\
\text { surface, the color } \\
\text { changes and an odor } \\
\text { appears, rancidity and } \\
\text { souring of the product } \\
\text { can be observed. The } \\
\text { development of } B \text {. } \\
\text { cereus in canned food is } \\
\text { accompanied by the } \\
\text { formation of a wall ring } \\
\text { at the border of the } \\
\text { product and packaging } \\
\text { and the precipitation of } \\
\text { a white precipitate at } \\
\text { the bottom of the } \\
\text { container. }\end{array}$ \\
\hline
\end{tabular}




\begin{tabular}{|c|c|c|c|}
\hline & & & Table 1 (Continue) \\
\hline $\begin{array}{l}\text { Microorganism } \\
\text { type, } \\
\text { Determination } \\
\text { method }\end{array}$ & $\begin{array}{l}\text { Microorganism type, } \\
\text { Determination method }\end{array}$ & $\begin{array}{c}\text { Microorganism type, } \\
\text { Determination } \\
\text { method }\end{array}$ & $\begin{array}{l}\text { Microorganism type, } \\
\text { Determination method }\end{array}$ \\
\hline $\begin{array}{l}\text { Staphylococcus } \\
\text { aureus, } \\
\text { ISO 6888-3:2003 }\end{array}$ & $\begin{array}{l}\text { Cells are spherical and } \\
\text { gram-positive, non- } \\
\text { spore forming in } \\
\text { diameter } 0,5-1,5 \mathrm{mkm} \text {. } \\
\text { Can form clusters of } \\
\text { irregular shape, } \\
\text { immovable, do not form } \\
\text { a spore; When viewed } \\
\text { microscopically, they } \\
\text { are seen as short chains, } \\
\text { pairs of cells or clusters } \\
\text { similar to grape } \\
\text { clusters. }\end{array}$ & $\begin{array}{l}\text { Metabolism is } \\
\text { respiratory and } \\
\text { fermentative, form a } \\
\text { catalase, use } \\
\text { carbohydrates to form } \\
\text { lactic acid under } \\
\text { anaerobic conditions, } \\
\text { acetic and } \mathrm{CO}_{2} \text { to } \\
\text { aerobic. The main } \\
\text { diagnostic test to } \\
\text { identify } S . \text { aureus, is } \\
\text { the ability to coagulate } \\
\text { blood plasma by the } \\
\text { enzyme coagulase. } \\
\text { Distinguish six } \\
\text { serotypes of entero- } \\
\text { toxins A, B, C, D, E } \\
\text { and F. The most } \\
\text { common enterotoxin } \\
\text { A which is synthesi- } \\
\text { zed by the cells in } \\
\text { exponential growth } \\
\text { phase. Pathogenicity } \\
\text { staphylococci } \\
\text { determine their ability } \\
\text { to produce a number } \\
\text { of toxins. Hemolysins, } \\
\text { dermatoxin, eucocidin, } \\
\text { enterotoxin, as well as } \\
\text { enzymes - plasmo- } \\
\text { coagulase, } \\
\text { hyaluronidase, } \\
\text { deoxyribonuclease, } \\
\text { etc. Facultative } \\
\text { anaerobes develop at } \\
\text { pH } \geq 4,2, \text { sensitive to } \\
\text { heat } \mathrm{D}_{60} \approx 3 \text { min. }\end{array}$ & $\begin{array}{l}\text { Foods contaminated } \\
\text { with staphylococci } \\
\text { usually do not have } \\
\text { external and } \\
\text { organoleptic signs of } \\
\text { spoilage. Staphylococci } \\
\text { can develop and } \\
\text { produce enterotoxin in } \\
\text { canned foods, } \\
\text { especially low-acid } \\
\text { foods. Reproduction of } \\
\text { pathogenic staphylo- } \\
\text { cocci and accumulation } \\
\text { of enterotoxin occurs } \\
\text { under aerobic } \\
\text { conditions at room } \\
\text { temperature without } \\
\text { visible organoleptic } \\
\text { changes in the product } \\
\text { for several hours. }\end{array}$ \\
\hline
\end{tabular}

Morphology and tinctorial features, which are given in Table 1, a number of physiological and some biochemical properties of regulated microorganisms that are the causative agents of food poisoning, as well as the classical methods for their determination, indicate a sufficiently profound study of these microorganisms. However, despite the popularity and standardization of methods, their disadvantage was low compared to the required promptness to obtain the necessary information (7 days for the identification of C. botulinum and when using the fastest biological test with mice, 48 hours). Standardized 
methods of analysis of $C$. perfringens (ISO 7937) provide for bacteriological culture, and serological analysis is used to detect enterotoxin. The duration of the procedure is 3 days. In determining trace amounts, for example, of staphylococcal enterotoxin in food products, the toxin should be isolated and concentrated before its serological identification. Currently, express methods based on the use of monoclonal antibodies, which have high efficiency, are being developed, since it is possible to detect toxin concentrations of the order of 1 nanogram per gram of food product.

Identification of pure cultures (up to the species of microorganism) is carried out taking into account the morphological, tinctorial, cultural, biochemical, toxigenic and antigenic properties of the microorganism [20-22]. The used (classical) B. cereus identification method is based on the isolation of pure culture on the MYP medium of the Mossel-yolk agar with mannitol, polymyxin and phenol red, and subsequent biochemical testing of the isolated culture [23], which requires of a considerable time [24]. In this regard, the question of developing an accelerated reliable method of identification of $B$. cereus is still relevant.

To identify individual species, immunological methods are often used. They are the agglutination reaction, immunoelectrophoretic analysis of antigenic components, immunofluorescence methods [1, 2, 23]. Most studies involve the determination of susceptibility to antimicrobial agents in the isolated pathogen. For the epidemiological assessment of the role of the microorganism, an intraspecific identification is carried out by the definition of phage, biovars, resistants, etc. Such studies are material and laborintensive, long-lasting, often do not correspond to the shelf-life of food products and, as we noted in studies, do not always allow the microorganism to be accurately established.

The need to improve methodological approaches to the diagnosis of these microorganisms is necessary, and among the methods of microbiological control of food production a special place should be taken by precise, relatively rapid molecular genetic methods.

\section{Molecular genetic methods of microbiological control of regulated microorganisms}

The use of molecular genetic methods for the sanitary control of food safety is a relatively new approach in the genotypic diagnosis of regulated microorganisms. Foreign and domestic scientists developed DNA analysis technologies that include DNA methods, in particular, polymerase chain reaction (PCR), multiplex PCR, reverse transcription PCR, qualitative or quantitative real-time PCR with various fluorescent systems. TagMan probes, SYBR Green et al., DNA hybridization methods, in particular FISH, as well as isothermal amplification (RSA, SDA) [24-27]. Such methods can be used in practice in the sanitary control of food products in establishing their safety by identifying pathogenic and opportunistic pathogens of foodborne infections and toxic infections, monitoring the quality of raw materials and the technological process of its processing. Molecular genetic methods can be used in scientific forecasting when studying regulated microorganisms and evaluating microbiological risks, as well as for identifying nucleotide sequences-toxicity genes responsible for the pathogenic properties of microorganisms [28-29].

There are test systems for the microbiological analysis of clostridia and other anaerobes [30]: F5110 SureFast ${ }^{\circledR}$ Clostridium botulinum Screening PLUS, F5123 SureFast ${ }^{\circledR}$ C. perfringens Screening PLUS, based on DNA determination by PCR, which, according to the developer, are the most accurate way to determine Microorganisms. 
Currently, seven serologically different types of neurotoxins (A, B, C, D, E, F and G) are known to be produced by the corresponding strains of $C$. botulinum, which have similar sizes and molecular organization. These are large enough proteins, consisting of two polypeptide chains - light (50-59 kDa) and heavy (85-105 kDa), which block the release of the mediator - acetylcholine. Despite the fact that botulism has been known for more than 200 years, at present the detailed mechanism of neurotoxins at the molecular level has not been sufficiently studied. It is believed that the neuroparalytic effect of the toxin is achieved as a result of the passage of 3 stages: the binding of a toxic molecule to the membrane surface, the energy-dependent penetration of a part of the molecule into the cell and the inhibitory stage. Medicines against botulism do not exist now [31]. It is believed that human botulism is caused by four types of neurotoxins A, B, E and F. In addition to the classic strains of $C$. botulinum, it has been found that other microorganisms, for example $C$. butyricum, producing the type E neurotoxin, may be the cause of botulism and C. barati, producing neurotoxin type $\mathrm{F}$.

As noted in [31], a PCR method for the identification of C. botulinum types A and B has been developed, which has high specificity and sensitivity (1 pg DNA), which can be used in diagnostic laboratories to identify these microorganisms. The PCR method is simple in execution, it ensures quickness of the results (less than 5 hours from the beginning of the study) and is especially convenient in cases when it is necessary to test a large number of samples.

As is known, C. perfringens is the causative agent of food-borne diseases, necrotic enteritis, gas gangrene $[32,33]$. Strains B and D produce $\mathcal{E}$-toxin, which leads to edema of the organs due to the formation in the cells of the channels through which the potassium ions emerge. Strain A causes food-borne diseases. There is a priority method for the PCR determination of $C$. perfringens [34], as well as the methodology for conducting research [35].

In addition, in the literature, there is sufficient information on the pathogenic properties and methods of determining Staphylococcus aureus [36-38].

Particular attention is currently being paid to bacillary pathogens of foodborne diseases, because, thanks to the development of molecular genetic methods, it has become known that not only microorganisms of the Bacillus cereus group (including 6 representatives), but a number of other bacilli are capable of producing toxicity genes [1, 2]. As noted in [23], during the study of 114 samples of raw milk for the presence of bacilli, it was found that the bacilli (B. cereus, B. subtilis) were preserved even after heating for 10 minutes at $80{ }^{\circ} \mathrm{C}$, in $21 \%$ of samples from pasteurized ham samples microorganisms of the genus Bacillus (the most common were $B$. cereus, B. subtilis, B. licheniformis), and sporeforming $B$. cereus were isolated from boiled sausages. It is indicated that 95 strains of bacilli were isolated and identified from wheat flour. Among the 53 strains isolated from the cooled dough, 24 strains were $B$. subtilis, 17 were B. cereus, 10 were B. pumilis, 2 were $B$. licheniformis. Our studies also show an abundance of bacillary contamination of plant $[39,40]$ and animal products $[41,42]$.

The presence of $B$. cereus or its toxins in food products is identified by morphological, biochemical, serological (ELISA), chemo-taxonomic and molecular genetic (PCR) methods [43]. It is possible to detect a toxin that causes vomiting, with the help of animal models (cats, monkeys) and cellular ones. The most common classical method of B. cereus identification is based on the isolation of pure culture on the MYP medium (the Mosellyolk agar), and subsequent biochemical testing of the isolated culture [23]. However, the instability of $B$. cereus enzymatic reactions hampers the interspecies differentiation of the bacteria of the first morphological group of the genus Bacillus and, in addition, requires 
considerable time-consuming [44]. In this regard, the question of developing an accelerated reliable method of identification of $B$. cereus is still relevant. Under experimental administration, the subcutaneous method of $B$. cereus is caused by disorders of the function of the gastrointestinal tract, lethargy, inhibition of movements. With the introduction of large doses of these microorganisms, the disease develops sharply, with a rapidly advancing $(10-16 \mathrm{~h})$ lethal outcome. At morphological research in organs of the fallen animals hemorrhages, inflammatory and necrotic changes are observed. To the greatest extent these lesions are recorded in the intestines, liver, heart muscle and in the brain. The authors [23] based on the traditional method developed a new scheme for isolating $B$. cereus, dividing the objects of the study into 2 groups, depending on the form in which the causative agent (vegetative or spore) is located. This scheme allows typing of B. cereus pathogen within 45 days due to expansion by additional biological tests (Fig. 1) [23].

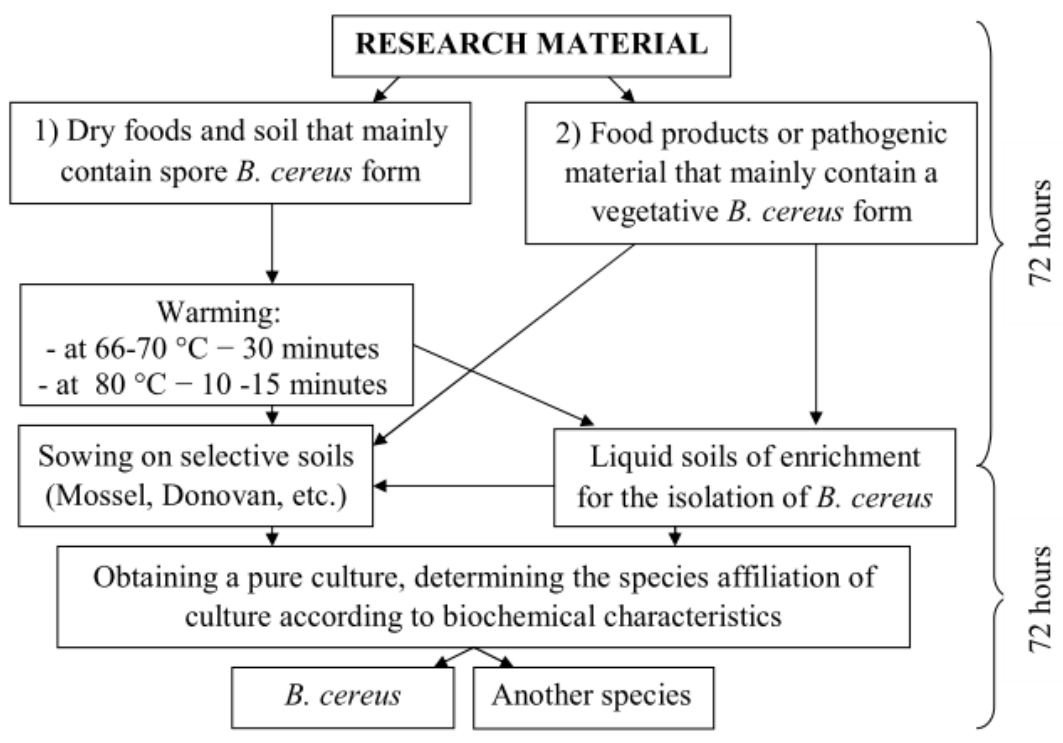

Total: 4-5 days

Figure 1. Scheme of identification of the causative agent $B$. cereus

The scheme shown in Figure 1, despite the length and laboriousness, does not make it possible to diagnose the presence of all bacillary representatives-carriers of toxicity genes capable of producing the corresponding toxins and confirms the need for an improved microbiological control methodology.

Modern works of a number of foreign researchers have shown that bacillary microorganisms synthesize genes that cause the ability of $B$. cereus to cause diarrheal and emetic syndromes [44-47]. B. cereus causes diarrhea and emetic syndromes, producing various extracellular toxins, including the three main types of enterotoxins, namely hemolysin BL $(h b l)$, nonhemolytic enterotoxin (nhe) and cytotoxin $\mathrm{K}(c y t K)$ [48]. Eight new pairs of PCR primers were developed and effectively detected eight toxin genes $h b l C, h b l D, h b l A$, nheA, nheB, nheC, cytK and entFM) in 411 strains of $B$. cereus (121 and 290 isolated from food and soil) and 205 strains $B$. thuringiensis. 
The presence of $h b l A C D$ genes in all 70 tested isolates from ready-to-eat vegetables in South Korea, detection of one or more $h b l$ genes in $23.5-70.6 \%$ of $B$. cereus group isolates from food products in Brazil, detection of hblA in all $57 \mathrm{~B}$. cereus isolates from raw vegetable samples collected in Mexico City, detection of $h b l A$ and $h b l D$ in $72 \%$ of B. cereus isolates from retail spices in the USA, $h b l C$ in $71 \%$ of these isolates are noted in the literature and testify to the relevance of such studies [45, 47-50].

Recently, scientific works on the differentiation of living and dead cells of bacillary pathogens of food poisoning have appeared [51,52].

Among the strains of $B$. cereus, enterotoxigenic genes $h b l A$, nhe $A$, cyt $K$ and $F m$ (enterotoxin FM) were widely spread. However, we selected only the $n$ he $A$ gene for PCR, given its greatest prevalence and detectable visual toxicity, which is associated with a major role in food poisoning [39, 41, 42]. The PCR with specific primers nhe $A \mathrm{~F}$ and nhe $A \mathrm{R}$, matched to the site of the nhe $A$ gene, confirmed the belonging of all tested collection strains of $B$. cereus to the enterotoxigenic species of $B$. cereus, whereas in PCR analysis of the DNA of the collection species G. stearothermophilus and Paenibacillus polymyxa and in negative control (PCR mixture without DNA), no amplification products were detected.

Thus, the substantiation of the methodology and the development of accelerated molecular genetic methods of microbiological control are relevant in improving the control of food safety.

\section{Conclusions}

Analysis of modern requirements for the sanitary safety of food has shown the need for microbiological control for the presence of heat-resistant microorganisms, which are potential pathogens of foodborne diseases.

Investigation of the control criterion microbiological indicators regulated types of microorganisms such as Clostridium botulinum, Bacillus cereus, Clostridium perfringens, Staphylococcus aureus showed failure phenotypic diagnosis due to the similarity of morphological and tinctorial properties within the individual groups, the variability of a number of biochemical parameters, weak antigenicity of a number of toxins, The emergence of new metabolic features associated with the ability to synthesize the toxicity genes by microorganisms, which are traditionally considered to be non-pathogenic, laborious and lengthy analysis.

Genotypic diagnostics of microorganisms using modern molecular genetic methods and methodologies that allow for accelerated microbiological control of food safety taking into account the characteristics of their composition and properties, the accuracy of identification, the ability to monitor and predict the behavior of infectious agents of foodborne infections and toxic infections in products in assessing microbiological risk are relevant, especially in the Ukrainian region.

\section{References}

1. Dzhej Dzh. M., Lessner M. Dzh., Gol'den D. A. (2014), Sovremennaja pishhevaja mikrobiologija, BINOM, Moscow.

2. Blackburn Clive de W. (2006), Food spoilage microorganisms, CRC Press, Woodhead Publishing Ltd., Cambridge. 
3. Thomson B., Rose M. (2011), Environmental Contaminants in the light of Climate Change, Quality Assurance and safety of Crops \& Foods, 3, pp. 2-11.

4. Steele R. (2004), Understanding and measuring the shelf-life of food, CRC Press, Woodhead Publishing Ltd., Cambridge, England.

5. Pylypenko L.N., Verhivker Ja.G., Pylypenko I.V. (2015), Konservirovanie pishhevyh produktov. Mikrobiologija, jenergetika, kontrol': monografija, BMB, Odesa.

6. Kleter G.A., Parandini A., Filippi L., Marvin H.J.P. (2009), Identification of potentially emerging food safety issues by analysis of reports published by the European Community's Rapid Alert System for Food and Feed (RASSF), Food and chemical toxicology, 47(5), pp. 932-950.

7. Verkhivker Ja., Pylypenko L., Pylypenko I. (2015), Microbiology, energy, packing and control of the canning production: scientific publication, LAP LAMBERT, Academic Publishing, Saarbrücken.

8. (2005), On strategy for setting microbial criteria for foodstuffs in Community legistration, SANCO/1252/2001, European commission health \& consumer protection directorate-general, Brussel, Rev. 11, pp. 34, Available at: http://ec.europa.eu/food/food/biosafety/salmonella/discussion_paper_en.pdf.

9. Mortimore S.E., Wallace C.O. (2013), HACCP: A Practical Approach, Springer Science \& Business Media.

10. SANCO/4198/2001 (2005), Draft commission regulation of on microbiological criteria for foodstuffs. Rev. 21 (final), Commission of the European communities, Brussels.

11. World Health Organization (2013), The International Food Safety Authorities Network (INFOSAN). WHO, Available at: http://www.who.int/foodsafety/fs_management/ infosan/en/.

12. Melngaile A. (2013), Microbiological risk analysis in catering establishments, Proceedings of the Latvian academy of sciences, Section B, 67(№ 4/5 (685/686)), pp. 340-349.

13. Craig P., Burca G. de. (2011), EU Law: Text, Cases, and Materials. Cambridge University Press, Cambridge.

14. Pylypenko Yu.D., Mazurenko I.K., Pylypenko I.V., Pylypenko L.M. (2009), Derzhavni normatyvni dokumenty na syrovynu, napivfabrykaty, materialy ta konservovanu produkciyu. Pokaznyky bezpechnosti ta yakosti, Minagropolityky, Kuiv.

15. (2015), Public Health England, Identification of Bacillus species, UK Standards for Microbiology Investigations, 9(3), Available at: www.gov.uk/uk-standards-formicrobiology-investigations-smi-quality-and-consistency-in-clinical-laboratories.

16. Roberts G.R. (1986), Bezvrednost pishchevykh produktov, Agropromizdat, Moscow.

17. Babarin V.P (2006), Sterilizatsiia konservov: Spravochnik, GIORD, Sanct-Peterburg, pp. 312.

18. Pylypenko Inna, Pylypenko Liudmyla, Sevastyanova Elena, Kotlyar Evgeniy, Kruchek Ruslana (2016), Epiphytic and regulated microbial contaminants of food vegetable raw materials and products, Ukrainian Food Journal, 5(2), pp. 272-280, DOI: 10.24263/2304-974X-2017-6-1-3

19. Persianova I.P., Gerasimenko L.N., Stojanova L.A. (2010), Mikrobiologija konservirovanija $i$ mikrobiologicheskij kontrol konservnogo proizvodstva, Vneshreklamservis, Odesa.

20. (2005), Bergey`s Manual of systematic bacteriology. The Proteobacteria. Part A., Bergey s Manual Trust Department of Microbiology and Molecular Genetics Michigan State University, $2^{\text {nd }}$ ed., Vol. 2, pp. 317-321. 
21. Harley J.P., Prescott L.M. (2002), Laboratory Exercises in Microbiology, Fifth ed., McGraw Hill Companies, pp. 466.

22. Netrusov A.I. (2005), Praktikum po mikrobiologii: Akademija, Moscow.

23. Vasilev D.A., Kaldyrkaev A.I., Feoktistova N.A., Aleshkin A.V. (2013), Identifikatsiia bakterii Bacillus cereus na osnove ikh fenotipicheskoi kharakteristiki, Ulianovsk.

24. Efimochkina N. R. (2007), Molekuliarno-geneticheskie metody v identifikatsii pishchevykh patogennykh bakterii, Voprosy pitaniia, 2, pp. 4-15.

25. Shimizu, S., Ootsubo, M., Kubosawa, Y., Fuchizawa, I., Kawai, Y., Yamazaki, K. (2009, June). Fluorescent in situ hybridization in combination with filter cultivation (FISHFC) method for specific detection and enumeration of viable Clostridium perfringens, Food Microbiology, 26(4), pp. 425-431. DOI:10.1016/j.fm.2009.02.002

26. Tempowski J. (2002), Clostridium botulinum International Program of Chemical Safety. Poisons Information Monograph 858: Bacteria, World Health Organization.

27. Pylypenko I. (2015), Clostridium perfringens: characterization, biological activity, the indication in food, Technology audit and production reserves, 2(4), pp. 4-8, DOI: 10.15587/2312-8372.2015.39107.

28. (2006), Uskorennie metodi viyavleniya sanitarno-pokazatelnih $i$ patogennih microorganizmov s ispolzovaniem podlozhek "RIDA ${ }^{(R)} C O U N T^{\prime}$, Chisso Corporation, Yaponiya, Available at: http://www.fsetan.ru/library/doc/mr-02011-06-uskorennyiemetodyi-vyiyavleniya-sanitarno-pokazatelnyih-i-patogennyih-mikroorganizmov-sispolzovaniem-podlozhek-ridarcount-proizvodstva-chisso-corporation-yaponiya/.

29. Satina O.I. Quick and rapid methods for microbiological analysis, Available at: http://www.vniipp.ru/s11.pdf.

30. Mikrobiologicheskie metody analiza klostridii i drugikh anaerobov F5110 SureFast ${ }^{\circledR}$ Clostridium botulinum Screening PLUS, F5123 SureFast ${ }^{\circledR}$ C.perfringens Screening PLUS, Available at: www.stylab.ru/directory/microbiology/clostridium/

31. Shlepnikova O. V. (1995), Razrabotka metodov DNK-gibridizatsii i polimeraznoi tsepnoi reaktsii (PTsR) dlia identifikatsii Clostridium botulinum tipov A i B, PhD Thesis, Moscow.

32. Knapp O., Maier E., Benz R., Geny B., Popoff H.R. (2009), Identification of the channel-forming domain of Clostridium perfringens. Epsilon-toxin (ETX), Biochim. Biophys. Acta, 1788(12), pp. 2584-2593.

33. Adcock P. W., Saint C. P. (2001), Rapid Confirmation of Clostridium perfringens by Using Chromogenic and Fluorogenic Substrates, Applied and Environmental Microbiology, 67(9), pp. 4382-4384, DOI: 10.1128/aem.67.9.4382-4384.2001.

34. (2006), Patent 111266 Ukraine. Sposib viznachennia Clostridium perfringens v kharchovikh produktakh.

35. Kaprelyants L., Pylypenko I. (2013), The Modern Strategies of the Foodstuffs Safety and Quality Control Development, The Advanced Science Journal, 1(3), pp. 123-127

36. Pozdeev O.K. (2001), Meditsinskaia mikrobiologiia, GEOTAR-MED, Moscow.

37. Maerle A.V., Riazantsev D.Iu., Dmitrenko O.A., Petrova E.E., Komaleva R.L., Sergeev I.V., Trofimov D.Iu., Zavriev S.K. (2014), Opredelenie toksinov Staphylococcus aureus metodom immuno-PTsR, Bioorganicheskaia khimiia, 40(5), pp. 526-531, DOI: 10.7868/S013234231405011X.

38. Goriainova, G. M. (2004), Indikatsiia Staphylococcus aureus metodami DNKdiagnostiki v moloke i molochnykh produktakh, PhD Thesis, Moscow.

39. Inna Pylypenko, Liudmyla Pylypenko, AnnaYamborko, Elena Ilyeva, Evgeniy Kotlyar, Dmitriy Babenko (2017), Identification of bacillary microbial contaminants 
and food poisoning agents from Ukrainian plant raw materials and products, Ukrainian Food Journal, 6(1), pp. 7-19, DOI: 10.24263/2304-974X-2017-6-1-3

40. Pylypenko I. V., Pylypenko L.M., Ilieva O. S., Yamborko H.V., Svirzhevskyi O. M. (2017), Bacillus cereus: kharakterystyka, biolohichna diia, osoblyvosti vyznachennia v kharchovykh produktakh, Kharchova nauka i tekhnolohiia, 11(2), pp. 61-67, DOI: 10.15673/fst.v11i2.515.

41. Kotliar Ye., Topchiy O., Pylypenko L., Pylypenko I., Sevastyanova E. (2017), Development of sanitary safe pastry products from poultry meat balanced by fatty and vitamin composition, Eastern-European Journal of Enterprise Technologies, 3/11(87), pp. 61-70, DOI: 10.15587/1729-4061.2017.103913

42. Kotliar Y., Topchiy O., Pylypenko L., Pylypenko I., Sevastyanova E., (2017), Complex of chemical-technological and sanitary-hygienic quality indicators of the new pastry products of special nutrition, EUREKA: Life Sciences, 3(9), pp. 35-42, DOI: $10.21303 / 2504-5695.2017 .00363$

43. Tallent S. M. et al. (2012), Efficient Isolation and Identification of Bacillus cereus Group Journal of AOAC International, 95(2), pp. 446-451.

44. Efimochkina N.R. (2010), Novye bakterialnye patogeny v pishchevykh produktakh: eksperimentalnoe obosnovanie i razrabotka sistemy kontrolia s primeneniem metodov mikrobiologicheskogo i molekuliarno-geneticheskogo analiza: PhD Thesis, Moscow.

45. Kim S.K., Kim K.P., Jang S.S., Shin E.M., Kim M.J., Oh S., Ryu S. (2009 Mar), Prevalence and toxigenic profiles of Bacillus cereus isolated from dried red peppers, rice, and Sunsik in Korea, J Food Prot., 72(3), pp. 578-582.

46. Puriya Ngamwongsatit, Wasin Buasri, Panuwat Pianariyanon, Chaiwat Pulsrikarn (2014 December), Detection of Toxigenic Bacillus cereus Strains Isolated from Vegetables in Mexico City, Journal of food protection, 77(12), pp. 2144-2147, DOI: 10.4315/0362-028X.JFP-13-479.

47. Park S.H., Kim H.J., Kim J.H., Kim T.W., Kim H.Y. (2007), Simultaneous detection and identification of Bacillus cereus group bacteria using multiplex PCR, J. Microbial Biotechnol., 17(7), pp. 1177-1182.

48. Connor N., Sikorski J., Rooney P. et al. (2010), Ecology of speciation of the genus Bacillus, Appl. Environ. Microbiol., 76, pp.1349-1358.

49. Flores-Urban Karen A., Natividad-Bonifacio Ivan, Vazquez-Quinones Carlos R., Vazquez-Salinas Carlos, Quinones-Ramirez, Elsa Irma (2014), Detection of Toxigenic Bacillus cereus Strains Isolated from Vegetables in Mexico City, Journal of Food Protection, 77(12), pp. 2144-2147. DOI:10.4315/0362-028X.JFP-13-479

50. Valero M., Hernandez-Harrero L. A., Fernandez P. S., and Salmeron M. (2002), Characterization of Bacillus cereus isolates from fresh vegetables and refrigerated minimally processed foods by biochemical and physiological tests, Food Microbiol, 19, pp. 491-499.

51. Zhihong Zhang, Lixia Feng, Hengyi Xu et al. (2016), Detection on viable enterotoxinproducing Bacillus cereus and analysis of toxigenicity from ready-to-eat foods and infant formula milk powder by multiplex PCR, J.Dairy Sci., 99(2), pp. 1-9, DOI: $10.3168 /$ jds.2015-10147.

52. Zhihong Zhang, Lijun Wang, Hengyi Xu et al. (2014), Detection of non-emetic and emetic Bacillus cereus by propidium monoazide multiplex PCR (PMA-mPCR) with internal amplification control, Food control, 35, pp. 401-406, DOI: 10.1016/j.foodcont.2013.07.035. 